\title{
Uma análise de discurso da política pública nacional de qualificação profissional em turismo
}

\author{
A discourse analysis of the national public policy of professional \\ qualification in tourism
Un análisis de discurso de la política pública nacional de calificación profesional en turismo

\author{
Ivan Conceição Martins da Silva ${ }^{1}$; Aguinaldo Cesar Fratucci ${ }^{1}$ \\ 1Universidade Federal Fluminense (UFF) Niteroi, RJ, Brasil.
}

Palavras-chave:

Políticas públicas; Qualificação professional; Complexidade; Análise de discurso; Ideologia.

\section{Keywords:}

Public policy; Professional qualification; Complexity; Discourse analysis; Ideology.

Palabras clave:

Políticas públicas; Calificación professional; Complejidad; Análisis del discurso; Ideología.
Resumo

\begin{abstract}
No campo do turismo, as políticas públicas nacionais de qualificação ganharam destaque nos últimos vinte anos. No entanto, existem dualidades na própria constituição da política de qualificação promovida pelo Ministério do Turismo e uma consequência da sua organização caótica é a falta de clareza dos rumos que a política aponta. Assim, o objetivo desta pesquisa é analisar a disputa política presente nos discursos sobre turismo, trabalho e educação que permeiam a política pública nacional de qualificação profissional em turismo. O percurso teórico-metodológico desta investigação possui três parâmetros: no campo epistemológico, o paradigma da complexidade; no campo metodológico, a análise do discurso; e, no campo teórico, as obras de Krippendorf, Freire e Marx. Como resultado, foram analisadas as formações discursivas do turismo (duro e suave), do trabalho (alienado e não alienado) e da educação (bancária e libertadora) e as formações ideológicas que os regem (do empresário e do ser humano). Diante dos antagonismos e complementaridades entre as duas formações ideológicas, a do empresário se impõe porque consegue incorporar as relações dialógicas e fazer com que a do ser humano atenda ao seu propósito.
\end{abstract}

Abstract

In the field of tourism, national policies of qualification have gained prominence in the last twenty years. However, there are dualities in the very constitution of the policy of qualification promoted by the Ministry of Tourism and a consequence of its chaotic organization is the lack of clarification of the direction that the policy points. Thus, this research aims to analyze the political dispute present in the discourses of tourism, work and education that cross the national public policy of professional qualification in tourism. The theoretical and methodological path of this research has three parameters: in the epistemological field, the complexity paradigm; in the methodological field, the discourse analysis; and, in the theoretical field, the works of Krippendorf, Freire and Marx. As a result, the discursive formations of tourism, (hard and soft), work (alienated and non-alienated) and education (banking and liberating) and the ideological formations that govern them (of business and of human beings) were analyzed. In the face of antagonisms and complementarities between the two ideological formations, the one of business establishes dominance because it manages to incorporate dialogical relations and make the one of human being serve its purpose.

Resumen

En el ámbito del turismo, las políticas públicas nacionales de cualificación han cobrado protagonismo en los últimos veinte años. Sin embargo, existen dualidades en la propia constitución de la política de cualificación impulsada por el Ministerio de Turismo y una consecuencia de su caótica organización es la falta de claridad de la dirección que apunta la política. Así, el objetivo de esta investigación es analizar la disputa política presente en los discursos sobre turismo, trabajo y educación que 
Revisado em pares.

Recebido em: 10/09/2020.

Aprovado em: 12/04/2021.

Editor:

Glauber Eduardo de Oliveira Santos

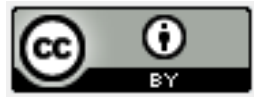

atraviesan la política pública nacional de calificación profesional en turismo. El recorrido teóricometodológico de esta investigación tiene tres parámetros: en el campo epistemológico, el paradigma de la complejidad; en el campo metodológico, análisis del discurso; y, en el campo teórico, las obras de Krippendorf, Freire y Marx. Como resultado, se analizaron las formaciones discursivas del turismo (duro y blando), del trabajo (alienado y no alienado) y de la educación (bancaria y liberadora) y las formaciones ideológicas que las gobiernan (de los empresarios y del ser humano). Ante los antagonismos y complementariedades entre las dos formaciones ideológicas, la de los empresarios establece el dominio porque logra incorporar las relaciones dialógicas y hacer que la del ser humano sirva a su propósito.

Como Citar: Silva, I. C. M.; Fratucci, A. C. (2022). Uma análise de discurso da política pública nacional de qualificação profissional em turismo. Revista Brasileira de Pesquisa em Turismo, São Paulo, 16, e-2250. http://doi.org/10.7784/rbtur.v16.2250

\section{INTRODUÇÃO}

A qualificação profissional é um fenômeno que, desde seu surgimento após a Segunda Guerra Mundial, tem uma crescente importância no funcionamento das sociedades capitalistas e em suas respectivas políticas públicas.

Embora muitas possam ser as concepções e correntes teóricas de abordagem ao conceito de qualificação profissional (Ferreti, 2004), as produções acadêmicas acerca do tema convergem sobre três aspectos: a qualificação possui um caráter processual; dimensões de educação, trabalho e política; e se aplica a setores econômicos (Silva, 2020).

O caráter processual da qualificação corresponde às suas etapas de planejamento (elaboração dos objetivos e rumos que a qualificação deve assumir), execução (as ações de qualificação em si) e resultados (formação de estudantes, empregabilidade dos profissionais, disponibilidade de mão de obra no mercado). Mesmo que essas etapas não sigam essa sequência de forma tão clara e distinta, esse processo pode ser observado tanto em ações de qualificação de natureza privada - como o caso das micro e pequenas empresas, estudadas por Pimentel, Paula e Oliveira (2016) - quanto de natureza pública - como o projeto de qualificação do Instituto Federal de Roraima (IFRR), analisado por Nogueira, Costa-Neto e Silva (2015).

Esse processo é composto por elementos que se relacionam aos campos da educação, do trabalho e da política. Por isso, a qualificação possui três dimensões: política (disputa de interesses pelos atores sociais envolvidos); educativa (processo de ensino-aprendizagem); e de trabalho (formação de profissionais e empregabilidade). Nas pesquisas do campo do turismo pode-se observar a dimensão política no trabalho de Maranhão et al (2010), que aponta a qualificação como eixo da política estadual do Rio Grande do Norte, a dimensão educativa na pesquisa mencionada de Nogueira, Costa-Neto e Silva (2015) e a dimensão de trabalho com a análise de Tomazoni (2007) sobre a capacidade da qualificação de gerar empregabilidade.

Terceiro, que ações de qualificação são sempre aplicadas a determinados setores econômicos, como saúde, informática e turismo. Catramby e Costa (2004) exemplificam isso, abordando o papel da qualificação profissional para a competitividade do setor do turismo.

De forma generalizada, todo processo de qualificação possui tais relações: ela é composta pelas dimensões política, educativa e de trabalho e é aplicada a setores econômicos. Porém, individualmente, a expressão prática de cada dimensão é amplamente variável. Por exemplo, enquanto Parente e Moesch (2016) apontam a possibilidade de uma qualificação que fortaleça a cidadania e o trabalho digno, Conceição, Fraga e Conceição (2016) relatam uma experiencia de qualificação mecanicista e irrefletido. Isso ocorre porque os atores sociais envolvidos disputam, nas ações de qualificação, a predominância de concepções ideológicas de trabalho e educação que estejam alinhadas aos seus respectivos interesses de classe e perspectivas ideológicas. Entre estes atores, pode-se destacar: o estudante/trabalhador, interessado na própria formação e empregabilidade; o empresariado, interessado na disponibilidade de profissionais; as instituições educativas, interessadas na execução dos processos educacionais; e o Estado, responsável por mediar os conflitos e interesses, além de prover profissionais para os diversos setores econômicos da sociedade.

Como dito, essa disputa de interesses entre atores sociais envolvidos é o que caracteriza a dimensão política da qualificação profissional. De acordo com Frey (2000) a política é formada por uma relação recursiva entre as instituições, a disputa de interesses e as políticas públicas - relação na qual a política pública é a materialização dos interesses dos atores em disputa acerca de determinada questão social. Dessa forma, identificar as 
concepções ideológicas predominantes em uma política pública permite rastrear o posicionamento ideológico dos atores interessados nela e as dinâmicas de complementariedade ou contradição entre tais posicionamentos.

No campo do turismo, políticas públicas de qualificação específicas para o setor ganharam destaque nos últimos vinte anos, culminando no lançamento de uma política protagonizada pelo Ministério do Turismo (MTur) em 2018 (Meira, Kushano \& Neves, 2018). A Política Nacional de Qualificação Profissional em Turismo (PNQT) representa um arranjo institucional inédito por ser a primeira política de qualificação elaborada e promovida pelo MTur diferente dos programas anteriores, que ora eram desdobramentos de políticas da Educação ou do Trabalho, ora eram iniciativas pontuais do MTur. Apesar deste destaque da PNQT, o contexto histórico da sua instituição é amplamente complexo.

A partir de 2011 os Planos Nacionais de Turismo (PNT) do MTur tiveram uma descontinuidade (Vilela \& Costa, 2020). De acordo com a Lei Geral de Turismo (Brasil, 2008), o PNT é o instrumento pelo qual o MTur define os rumos da Política Nacional de Turismo. Isso significa que nos períodos em que não houve PNT instituído as ações do MTur acontecerem sem uma diretriz programática. Um desses períodos foi entre 2017 e 2018. Durante esse tempo, o MTur criou um pacote de ações chamado Brasil + Turismo que incluía cinco ações de qualificação profissional: curso Brasil Braços Abertos (BBA); Curso Gestor de Turismo (CGT); Programa de Qualificação Internacional em Turismo e Hospitalidade (PQI); Pronatec 2017; e MédioTec Turismo.

Em meados de 2018 foi instituído o PNT 2018-2022. Entretanto, no âmbito da qualificação em turismo, esse PNT estabeleceu a PNQT ao mesmo tempo em que validou as iniciativas do Brasil + Turismo, mesmo que os direcionamentos dessas duas correntes fossem conflitantes em muitos aspectos. Na prática, isso significa que a política pública nacional de qualificação profissional em turismo, como ação do poder público na pasta do Turismo, inclui tanto a PNQT quanto o Brasil + Turismo, não podendo ser reduzida a nenhum dos dois isoladamente.

Portanto, existem dualidades na própria constituição da política de qualificação promovida pelo MTur: a PNQT e o Brasil + Turismo como correntes da política de qualificação criadas em momentos diferentes, com arranjos políticos e objetivos diferentes. Uma das consequências dessa organização caótica é a falta de esclarecimento dos rumos que a política pública aponta. Afinal, quais atores são efetivamente beneficiados pelas posições ideológicas predominantes nessa política e como cada um é afetado?

Desta forma, o objetivo desta pesquisa é analisar a disputa política presente nos discursos sobre turismo, trabalho e educação que atravessam a política pública nacional de qualificação profissional em turismo. A pesquisa tem como recorte temporal os anos de 2017 e 2018. Nesse período, a ação do MTur sobre qualificação profissional assumiu um contorno específico, carregando contradições que refletem o próprio caráter conturbado do arranjo político-institucional do momento. Até 2016 a política de qualificação profissional era norteada pelo PNT 20132016, concentrada no Pronatec Turismo - programa já estudado em pesquisas sobre empregabilidade (Fratucci, Bantin \& Melo, 2017), ensino (Cisne, 2016) e avaliação (Feger et al, 2015).

Em 2017 esse cenário muda, com o lançamento do pacote de medidas Brasil + Turismo e suas ações de qualificação (que também incorporam o Pronatec Turismo, porém apenas como parte e não mais como foco estruturante). Essa multiplicidade de ações permanece em 2018, unindo-se à PNQT por meio da institucionalização de ambas correntes de ação via PNT 2018-2020. Embora a política de qualificação do MTur não tenha sofrido mudanças drásticas a partir de 2019, a entrada de uma nova gestão no Governo Federal coloca outra forte mudança no arranjo institucional.

A partir de 2019, novas ações são criadas, enquanto as antigas são redimensionadas, tanto em amplitude quanto em objetivos. Por isso, tendo em vista que seria necessária uma outra análise para a política de qualificação na gestão sequente, o recorte temporal da presente pesquisa se encerra em 2018. Quanto à política, foram contempladas nesta pesquisa as iniciativas da PNQT e do Brasil + Turismo. 0 corpus de análise foi composto por documentos oficiais do MTur de apresentação e regulação das iniciativas contempladas. No total foram 15 documentos analisados, descritos na seção 2 .

Para alcançar o objetivo apresentado, o percurso teórico-metodológico desta pesquisa foi baseado em três parâmetros. Primeiro, no campo epistemológico, o paradigma da complexidade (Morin, 2005) orientou toda a reflexão do processo de pesquisa e análise. Segundo, no campo metodológico, foi utilizada a Análise de Discurso (Orlandi, 2003; 2015; Brandão, 2012) como método de análise dos documentos selecionados. Terceiro, no campo 
teórico, foram utilizadas teorias de Krippendorf (2003), Freire (2016) e Marx (2008) como ferramentas de interpretação e análise. A descrição detalhada do percurso metodológico está apresentada na seção 2.

A partir desses parâmetros teórico-metodológicos, especialmente da Análise de Discurso (AD), é possível apontar como justificativa da presente pesquisa a elucidação da ideologia dominante na política pública analisada e da forma de dominância que essa ideologia empreende. A busca, caracterização e análise dos discursos e ideologias que atravessam uma política pública permitem superar os significados explícitos no texto sobre quais benefícios são gerados para cada ator social, alcançando-se o funcionamento ideológico da política e, consequentemente, seus reais benefícios e beneficiados. 0 método de AD serve, assim, para revelar os interesses subjacentes na atuação política do Estado.

Dessa forma, pretende-se, com essa pesquisa, contribuir com informações sobre o real posicionamento ideológico nela predominante. As políticas públicas representam a ação do Estado sobre questões sociais. Dado que o Estado é gerido por uma classe política que regula os conflitos entre trabalhadores e capitalistas (Mascaro, 2013), a ciência sobre as ideologias predominantes na política de qualificação do MTur pode servir como ferramenta para os atores sociais nela envolvidos desenvolverem um conhecimento crítico sobre os efeitos dela e uma ação política sobre ela, conscientes da importância de defender seus interesses frente à disputa política nela materializada.

\section{BASES EPISTEMOLÓGICA, METODOLÓGICA E TEÓRICA DA PESQUISA}

O fundamento epistemológico da presente pesquisa é a teoria da complexidade, conforme sistematizada por Edgar Morin. Parte dessa teoria é dedicada à defesa de uma forma de pensar os objetos de estudo de forma integrada e harmônica. Em contraste com os paradigmas anteriores, que, segundo Morin, operaram uma disjunção, uma separação dos saberes, a complexidade deve buscar a religação dos saberes (Morin, 2005). Nesse sentido, a complexidade se mostra como um paradigma bastante adequado para a investigação do objeto qualificação profissional.

Conforme apresentado na seção 1, a qualificação profissional é um processo inter-relacionado aos campos da educação, do trabalho e da política, bem como às especificidades de determinados setores econômicos. Soma-se a estas características próprias do processo de qualificação, o fato desta ser objeto de políticas públicas, que carregam também uma inter-relação com disputas políticas, conforme demonstram Parente e Moesch (2016) e Meira, Kushano e Neves (2018). Encontra-se na qualificação, assim, um objeto de estudo que demanda um olhar complexo, que ligue os saberes de diversos campos para analisar seu funcionamento altamente dinâmico.

Para Morin (2005), a busca pela complexidade do real passa pela articulação de macroconceitos, representados, em sua teoria, por três princípios.

Primeiro, o princípio dialógico corresponde à associação de "dois termos ao mesmo tempo complementares e antagônicos" (Morin, 2005, p. 74). A dialógica visa superar polarizações simplificadoras e reintegrar a dualidade à unidade. Morin dá como exemplo, a noção da física de que um elétron é ao mesmo tempo corpúsculo e onda (duas coisas contrárias, mas também iguais).

Segundo, o princípio da recursão organizacional representa um avanço na causalidade linear (na qual a causa gera resultado) e na causalidade retroativa (na qual o efeito retroage na causa). A recursão é uma lógica de causalidade “em que os produtos e os efeitos são ao mesmo tempo causa e produtores do que os produz" (Morin, 2005, p. 74). Por exemplo: o indivíduo é produzido pela sociedade (via linguagem, cultura, trabalho, etc), ao mesmo tempo que produz a sociedade.

Terceiro, o princípio hologramático se baseia na compreensão de que da mesma forma que uma totalidade é composta das suas partes, cada uma dessas partes possui em si a totalidade (Morin, 2005). Cada parte de um sistema é um holograma do todo sistêmico. Para esse princípio, Morin utiliza o exemplo do DNA, uma parte do organismo que está presente em células individuais (parte), mas que carregam a informação de todas as células possíveis de serem reproduzidas no organismo (todo).

Nesse sentido, os princípios apresentados norteiam todo o pensamento empreendido nesta pesquisa: seleção e reflexão dos referenciais teóricos, organização e aplicação do percurso metodológico, compreensão e análise do objeto de estudo.

O método empreendido nesta pesquisa foi a Análise de Discurso (AD), para a qual discurso e ideologia são conceitos centrais. De acordo com Orlandi, "a relação estabelecida pelos interlocutores, assim como o contexto, são 
constitutivos da significação de que se diz" (Orlandi, 2003, p. 157). Este apontamento alinha-se à compreensão de que a linguagem é formada por dois âmbitos: um, das marcas formais, os signos materiais; e outro, dos significados conferidos a eles. Na concepção da autora, esses significados não são pré-determinados ou isentos de contradição, mas construídos pelo próprio processo de interlocução em dada situação. Esse âmbito da significação representa o discurso. Assim, “o discurso é efeito de sentido entre locutores” (Orlandi, 205: 20).

Eagleton afirma que a AD surge a partir de “uma teoria materialista de ideologia” (Eagleton, 2019: 209). Nesse sentido, o discurso aparece, na $\mathrm{AD}$, como um âmbito intermediário, que dota o texto de significado, mas é dotado de significados pela ideologia. Assim, Brandão (2012: 11) aponta que o discurso é um "ponto de articulação dos processos ideológicos e dos fenômenos linguísticos". Orlandi esclarece esta articulação exatamente pela via do materialismo indicada por Eagleton, ao postular que "a materialidade específica da ideologia é o discurso e a materialidade específica do discurso é a língua” (Orlandi, 2015: 15).

Ambas, Orlandi (2003) e Brandão (2012), compartilham da concepção de ideologia como uma representação das posições de classe. De acordo com Brandão (2012), a linguagem é uma forma do ser humano se conectar com a realidade e, por isto, ela é sempre lugar de confronto ideológico. Isto é, as ideologias que representam diferentes classes sociais disputam a prevalência sobre a linguagem, pois esta é o meio pelo qual os indivíduos compreendem e agem sobre a realidade. É desta maneira que a AD extrapola a superfície do texto e mesmo os sentidos nele subjacentes para abarcar o funcionamento dos discursos materializados no texto e, consequentemente, das ideologias que esses discursos materializam.

Destaca-se aqui uma relação hologramática entre ideologia, discurso e texto. Estando a ideologia transposta em diversos discursos e o discurso expresso em diversos textos, é possível inferir que as partes formam o todo (o complexo de textos expressa a ideologia), mas também que o todo está imbuído no funcionamento de cada parte (o todo da ideologia está em cada texto individual). É a partir dessa relação hologramática que é possível, assim, fazer a remissão dos textos aos discursos e desses às ideologias.

O uso da AD no campo do turismo não é tão frequente quanto outros métodos de análise textual, como análise de conteúdo e análise documental. Entretanto, já existem pesquisas no turismo que utilizam a AD, especialmente em suas vertentes de base espanhola (Soares \& Godoi, 2017) e francesa (Souza, Gastal \& Campos, 2017; Moreira \& Campos, 2019). A aplicação do método da AD nesta pesquisa é baseada na vertente brasileira e se organiza a partir dos instrumentos de dispositivo teórico e dispositivo analítico, conforme sistematizados por Orlandi (2015).

O dispositivo teórico é um conjunto de referências teóricas explícitas usado como parâmetro para interpretação dos sentidos do texto. Já o dispositivo analítico é a operacionalização do dispositivo teórico como método, considerando o objeto e os objetivos da análise. Ambos funcionam em uma relação recursiva, pois não há relação estanque entre método e teoria. Assim, tanto o método de análise consta no dispositivo teórico quanto as teorias constituem o dispositivo analítico.

Cinco parâmetros compõem o dispositivo teórico utilizado nesta pesquisa:

- Teoria da AD, baseada em Brandão (2012) e Orlandi (2003; 2015).

- $\quad$ Teoria da Complexidade (Morin, 2005).

- Conceitos de turismo duro e turismo suave de Krippendorf (2003)

- Conceitos de trabalho alienado e trabalho não alienado de Marx (2008)

- Conceitos de educação bancária e educação libertadora de Freire (2016)

O primeiro parâmetro corresponde aos princípios teóricos para aplicação metodológica da AD. O segundo, como norteador epistemológico da pesquisa, também caracteriza a observação das teorias aplicadas e dos discursos analisados. Os três últimos são os parâmetros usados para identificar, na política, os discursos sobre turismo, trabalho e educação, respectivamente.

Conforme apontado por Orlandi e Brandão, a ideologia representa as posições das classes sociais. De acordo com Marx (2017), as sociedades modernas organizadas no sistema capitalista são divididas, essencialmente, em duas classes antagônicas: a classe trabalhadora e a classe capitalista. Mascaro (2013) apresenta o Estado como um ente terceiro indispensável à relação Trabalho-Capital e, com isso, teoriza uma terceira classe, a classe política, 
personalizada pelos gestores do Estado. Mesmo assim, Mascaro demonstra que, apesar da classe política exercer um papel diferenciado na luta de classes, ela não tem um interesse autônomo e sim uma atuação para defender os interesses de uma ou outra das classes trabalhadora e capitalista. As ideologias representam, portanto, posições de defesa dos interesses dos trabalhadores ou dos capitalistas.

Nesse sentido, a escolha das três teorias-parâmetros para identificação de discursos está baseada na contribuição que seus respectivos autores deram para analisar os campos do turismo, do trabalho e da educação a partir do conflito de classes na sociedade. 0 papel da teoria da complexidade como parâmetro foi justamente permitir a identificação das duas posições (trabalhadores/capitalistas) dentro das teorias, destacando suas dualidades (duro/suave; alienado/não alienado; bancária/libertadora) dentro da sua unidade (turismo; trabalho; educação). As três teorias serão apresentadas mais à frente.

Quanto ao dispositivo analítico, para sua construção foram articulados dois eixos de conceitos advindos da teoria da $A D$, conforme ilustrado na Figura 1.

Figura 1 - Processo de funcionamento do discurso

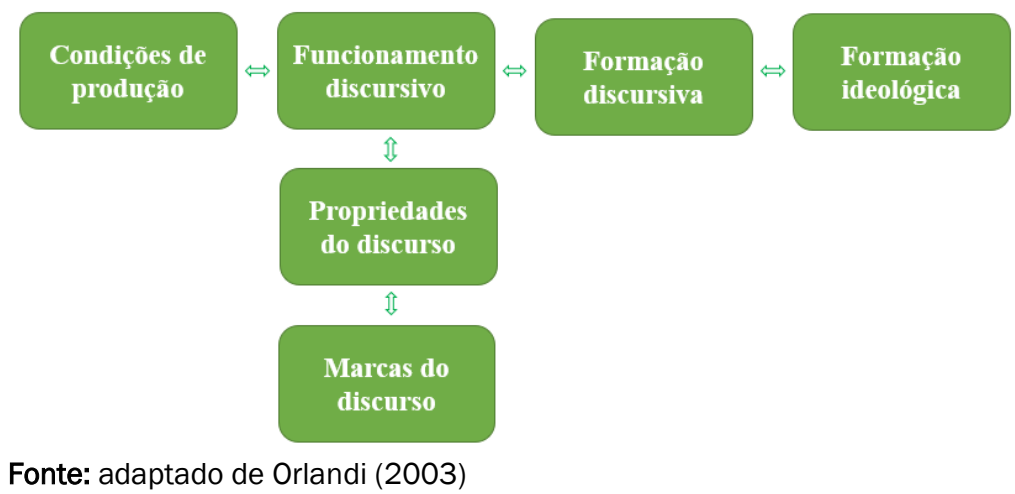

O eixo horizontal corresponde ao processo que ocorre para significação do texto, representado pelos conceitos de condições de produção, funcionamento do discurso, formação discursiva (FD) e formação ideológica (FI).

O discurso é construído processualmente e, com isso, não possui limites bem definidos: não é possível pontuar seu início e término temporalmente; nem demarcar fronteiras exatas com outros discursos (Orlandi, 2015). Por isso, é utilizado na AD o conceito de FD - e o mesmo ocorre com a ideologia, instrumentalizada como FI. Assim, discurso e ideologia não podem ser apreendidos como objetos fechados, mas como processos, como FD e FI (Orlandi, 2003). As FI iniciam o processo de significação da realidade a partir das relações de conflito de interesse das classes na sociedade (Orlandi, 2003; Brandão, 2012). As FD desempenham o papel de materializar as FI, isto é, transpor os sentidos para a linguagem e os textos (Orlandi, 2015).

Como o discurso não é um objeto fechado e encerrado em si, o processo da FD só pode ser apreendido como uma atividade organizada. Ou seja, o discurso não é um objeto/conteúdo contido ou escondido no texto, mas o processo que dá significado ao texto. Assim, a FD gera determinados significados por possuir determinado funcionamento discursivo. E as condições de produção do discurso são fatores que influenciam ou determinam a construção e o funcionamento do discurso (Orlandi, 2003; 2015).

O eixo vertical explicita o funcionamento discursivo, incluindo os conceitos de propriedades e marcas do discurso. Este processo, além de definir qual sentido terá o texto, a partir das FI, também define como esse sentido vai ser estabelecido.

De acordo com Orlandi (2003: 235-236) "as marcas dizem respeito à organização do discurso e as propriedades têm a ver com a totalidade do discurso e sua relação com a exterioridade". Assim, as marcas são os elementos formais da linguagem pelos quais se constroem os textos, enquanto as propriedades são as características do discurso na sua dotação de sentidos ao texto. Numa recursão organizacional, a propriedade dá sentido às marcas e as marcas materializam as propriedades. 
Observa-se que há, em ambos os eixos, uma relação recursiva entre os conceitos. Tanto o processo ideologia discurso - funcionamento - condições de produção quanto o de marcas - propriedades - funcionamento não são unidirecionais, mas ambivalentes: cada conceito produz e é produzido pelos seguintes.

A partir destes conceitos, o dispositivo analítico empreendido corresponde a um movimento recursivo entre corpus do objeto analisado e os preceitos teórico-metodológicos, expresso nos seguintes passos:

1. Delimitação do objeto: foram considerados 15 documentos relativos às cinco inciativas do programa Brasil + Turismo e à PNQT. São eles: PNQT (MTur, 2018h); Portaria n 8 (MTur, 2017b), que dispõe sobre as iniciativas BBA e CGT; Portaria n 46 (MTur, 2017a), que dispõe sobre o PQI; Lei $n^{\circ} 12.513$, de 26 de outubro de 2011 (Brasil, 2011), que instituiu o Pronatec; Guia MédioTec (MEC, 2017); página 'Perguntas Frequentes' do BBA (MTur, 2018b); página 'Sobre' do BBA (MTur, 2018c); página 'Perguntas Frequentes' do CGT (MTur, 2018d); página 'Sobre' do CGT (MTur, 2018e); página 'MédioTec' (MEC, 2018); página 'MédioTec presencial' (MTur, 2018a); página 'Perguntas frequentes' do PQI (MTur, 2013a); página 'Conheça o programa' do PQI (MTur, 2013b); página 'Perguntas Mais Frequentes - PRONATEC Voluntário EAD' (MTur, 2018g); página ‘Pronatec' (MTur, 2018f).

2. Recorte no objeto: Dedução das FD no texto da política, a partir das teorias de turismo, trabalho e educação do dispositivo teórico.

3. Inferência das marcas e propriedades das FD.

4. Análise do funcionamento discursivo das FD.

5. Identificação das FI que regem as FD analisadas.

6. Análise das FI.

A seguir é apresentado o referencial teórico (e metodológico) para os campos do turismo, trabalho e educação. Como indicado no dispositivo teórico, o embasamento da presente pesquisa advém das perspectivas de Krippendorf, Marx e Freire.

Krippendorf parte de um amplo fundamento teórico sobre a organização da sociedade em torno de espaços/processos de trabalho, moradia, lazer e viagem para teorizar as formas de turismo duro e suave. Ele entende que estes processos são inter-relacionados e propõe estas categorias a partir do que observa do funcionamento do turismo e do que idealiza como sociedade mais humanizada (Krippendorf, 2003). Embora o autor defenda a adoção de um dos modelos - o turismo suave - não é isto que se pretende na presente pesquisa; a utilização da teoria é em função da sua grande contribuição sobre o funcionamento do turismo em suas possibilidades. Entende-se que a teoria de Krippendorf aponta modelos possíveis com diferentes arranjos de benefícios e prejuízos aos atores sociais envolvidos no turismo.

De acordo com Krippendorf (2003, p. 151) "aquele que obedece apenas às coerções de ordem econômica e técnica é o ‘turismo duro'. Ninguém contestará que foi o 'turismo duro' que prevaleceu até o momento, em todos os lugares e sem nenhuma discriminação". Assim, o turismo duro é o modelo no qual os valores recaem sempre sobre as coisas em detrimento dos seres humanos: o ter sobre o ser; a economia sobre o meio ambiente e a sociedade; o ganho econômico do trade sobre a vida da população e a experiência do turista.

Já o turismo suave é aquele no qual "a política do turismo não estará mais centrada exclusivamente nas finalidades econômicas e técnicas, mas também respeitará o meio ambiente e levará em conta as necessidades de todas as pessoas envolvidas" (Krippendorf, 2003, p. 151). O autor coloca que esta forma, na qual todos os interesses, além da demanda ambiental, estejam contemplados equitativamente, não havia sido praticada. Entretanto, é possível observar exemplos e ações em prol de várias das características que comporiam este modelo e, portanto, a existência de um discurso que vai nesta direção.

As contribuições de Krippendorf têm bastante presença na produção científica brasileira, por exemplo na pesquisa de Rosa (2016) sobre sua categoria de turismo de massa. Assim, a teoria de Krippendorf permite observar modelos de turismo que podem privilegiar a classe capitalista (turismo duro) ou a trabalhadora (turismo suave).

No campo de estudos do trabalho, a teoria utilizada foi a de Karl Marx, no capítulo "Trabalho estranhado e propriedade privada” do livro Manuscritos econômico-filosóficos (Marx, 2008: 79-90). Nele, o autor analisa o funcionamento da economia no sistema capitalista e demonstra como este se baseia na alienação do trabalho. 
Sobre o trabalho alienado, Marx coloca que, em relação ao funcionamento da economia capitalista, "o trabalhador baixa à condição de mercadoria e à de mais miserável mercadoria” (Marx, 2008: 79). Esta afirmação já aponta o trabalhador como objeto e não sujeito do próprio trabalho.

Ele demonstra quatro formas de alienação, ou estranhamento, que o sistema capitalista implicou no ser humano e na sua atividade de trabalho:

- $\quad$ Alienação ao produto de seu trabalho: o produto do trabalho como um objeto estranho ao trabalhador que não Ihe pertence e que ele não reconhece;

- Alienação da própria atividade de produção: o trabalhador não entende ou reconhece a função do próprio trabalho e não Ihe dá significado;

- Estranhamento do gênero humano: ao estranhar produto e atividade do trabalho do ser humano, o trabalho alienado descaracteriza a própria espécie do ser humano - que se distingue dos demais animais pela natureza de seu trabalho consciente e refletido;

- Estranhamento do próprio ser humano: o ser humano estranha o próprio ser humano, na medida em que não se reconhece no produto, no trabalho nem no gênero humano (Marx, 2008).

De acordo com o autor: "Se o produto do trabalho não pertence ao trabalhador, um poder estranho [que] está diante dele, então isto só é possível pelo fato de [o produto do trabalho] pertencer a um outro homem fora do trabalhador" (Marx, 2008: 86, grifo do autor, inserção do tradutor). Desta forma, a alienação do trabalhador só tem lugar na medida em que um outro ser humano se faz dono do seu trabalho e do produto do seu trabalho.

No trabalho não alienado não existe a separação entre o trabalho e os efeitos que ele produz (o produto, a identificação, a distinção). De acordo com Marx, o trabalho é atividade distintiva e constitutiva do ser humano (Marx, 2008). 0 trabalho seria então uma atividade que caracteriza o ser humano - individualmente e como espécie - e, por isso, atividade e produto são partes do sujeito que os empreende - pertencendo a ele e sendo significados por ele.

Como um pilar do conhecimento sobre as sociedades capitalistas, naturalmente a teoria de Marx sobre a alienação demonstra as formas de trabalho que sustentam a burguesia (alienado) ou humanizam o proletariado (não alienado). Outras produções demonstram que as contribuições de Marx são fundamentais também para o campo do turismo (Martoni \& Alves, 2019)

No âmbito da educação, Freire construiu sua teoria a partir da sua percepção da realidade brasileira - com uma educação que servia à manutenção da opressão, encerrando educadores e educandos em posições hierarquizadas e estanques (educação bancária). Em contrapartida, com sua atuação e teoria, Freire apresenta a educação libertadora e problematizadora - na qual os sujeitos se reconheçam e se complementem para a prática educativa, problematizando ser humano, mundo e suas relações, e libertando-se dos mecanismos de opressão (Freire, 2016).

A educação bancária é meio de dominação e de permanência da situação de opressão. Nela, não se espera que os sujeitos questionem sua realidade e suas posições. E para isso, são cortados quaisquer princípios de criação e liberdade de pensamento. A partir de uma relação sem diálogo, na qual o educando apenas recebe conteúdos que deve armazenar em sua memória, tais conteúdos se tornam "retalhos da realidade desconectados da totalidade em que se engendram e em cuja visão ganhariam significação” (Freire, 2016: 103-104).

Quanto à educação libertadora e problematizadora, dois eixos marcam seu funcionamento. Primeiro, ela serve à libertação do pensamento e dos sujeitos da lógica de opressão. Move-se pelo "ânimo de liberar o pensamento pela ação dos homens uns com os outros na tarefa comum de refazerem o mundo e de torná-lo mais e mais humano". (Freire, 2016: 115). Ou seja, liberta das amarras de um sistema de dominação e permite recriar, repensar o mundo - ou a relação do ser humano consigo e com o mundo. Esse repensar e recriar vem justamente a partir do segundo eixo, da "problematização dos homens em sua relação com o mundo" (Freire, 2016: 118). Assim, o ser humano questiona a realidade, expressa as questões que Ihe afligem em lugar de ocultá-las - problematiza. Esta educação coloca educador e educando, ambos, como incompletos e como produtores do saber - permitindo que os sujeitos problematizem o mundo.

Portanto, também a teoria de Freire demonstra modelos de educação que servem à opressão pela classe burguesa (bancária) ou à libertação da classe trabalhadora (libertadora). No campo do turismo, Freire também já foi utilizado por Paula e Herédia (2019) para analisar a qualificação profissional do setor. 
Utilizando a perspectiva da complexidade (Morin, 2005), pode se identificar nas teorias de Krippendorf, Marx e Freire os modelos de turismo, trabalho e educação que refletem as ideologias das classes capitalista e trabalhadora. Conforme apontado no passo 2 do dispositivo teórico, esses seis modelos identificados nas teorias foram utilizados para deduzir as FD na política de qualificação analisada. A análise desses discursos será apresentada a seguir.

\section{DISCURSOS QUE ATRAVESSAM A POLÍTICA DE QUALIFICAÇÃO}

A apresentação das formações discursivas (FD) segue a ordem das teorias. Pretende-se enfatizar, nesta seção, contrastes entre as perspectivas no interior de cada teoria. A evidenciação sobre aproximações entre elas para remissão às formações ideológicas (FI) será abordada na próxima seção.

Começando pela FD de turismo duro, o funcionamento discursivo desta FD acontece pelos processos de falseamento e conflito, observados nas propriedades apresentadas no Quadro 1.

Quadro 1- Propriedades discursivas da FD de turismo duro
\begin{tabular}{|l|l|}
\hline \multicolumn{1}{|c|}{ Propriedades do discurso } & \multicolumn{1}{c|}{ Exemplos com as marcas formais } \\
\hline $\begin{array}{l}\text { 1: Encadeamento entre ações (verbos) e coisas (pro- } \\
\text { cessos) que leva da instituição até o todo coletivo } \\
\text { sem explicitar quem são os beneficiados de fato. }\end{array}$ & $\begin{array}{l}\text { "celebrar parcerias e instrumentos de cooperação técnica internacional } \\
\text { para a consecução do Programa, visando aprimorar a qualidade e a com- } \\
\text { petitividade do turismo brasileiro" (MTur, 2017b: s. p., grifo nosso). }\end{array}$ \\
\hline $\begin{array}{l}\text { 2: Inversão da ordem dos beneficiados da polí- } \\
\text { tica/programa na medida em que coloca o trabalha- } \\
\text { dor contemplado como meio/objeto para um final } \\
\text { que beneficia outro ator. }\end{array}$ & $\begin{array}{l}\text { "qualificação [que] busca aperfeiçoar profissionais do setor de turismo } \\
\text { para a melhoria da prestação dos serviços ofertados aos turistas" (MTur, } \\
\text { 2018c: s. p., grifo nosso). }\end{array}$ \\
\hline $\begin{array}{l}\text { 3: A valorização do interesse de um ator subentende } \\
\text { a desvalorização do interesse de outro. }\end{array}$ & $\begin{array}{l}\text { "Neste jogo-simulação, você pode começar com um preço mais alto e } \\
\text { acompanhar a reação do cliente. Quando ele recusa comprar a água, está } \\
\text { alto demais. Reduza o preço até que o cliente aceite, e analise bem os re- } \\
\text { sultados do lucro por dia e sua meta de lucro." (MTur, 2018b: s. p.). }\end{array}$ \\
\hline
\end{tabular}

Fonte: elaborado pelo autor.

O falseamento ocorre quando o verdadeiro beneficiado (destacadamente, o trade) é escondido atrás de processos aparentemente impessoais ou de outros atores. No exemplo da propriedade 1, coloca-se qualidade e competitividade como processos benéficos ao setor como um todo - quando favorecem mais o trade do que ao trabalhador. E na propriedade 2, a qualificação do trabalhador não serve a si mesmo, mas ao turista que receberá melhores serviços.

Já o conflito é o processo em que os interesses dos atores, quando confrontados, oprimem uns aos outros. Nas propriedades 1 e 2, os interesses do trade e do turista sobrepõem o do trabalhador. Na propriedade 3, é o interesse do trabalhador que sobrepõe o do turista: estimula-se que o preço a ser cobrado não seja um padrão da concorrência ou um equilíbrio de custo-benefício, mas puramente o valor máximo que cada turista individualmente esteja propenso a pagar.

Seguindo para a FD de turismo suave, do Quadro 2, apreende-se dois aspectos do seu funcionamento discursivo.

Quadro 2 - Propriedades discursivas da FD de turismo suave

\begin{tabular}{|l|l|}
\hline \multicolumn{1}{|c|}{ Propriedades do discurso } & \multicolumn{1}{c|}{ Exemplos com as marcas formais } \\
\hline $\begin{array}{l}\text { 1: Qualificação como um processo que distri- } \\
\text { bui benefícios para todos os atores envolvi- } \\
\text { dos no turismo. }\end{array}$ & $\begin{array}{l}\text { "a melhoria da qualificação profissional do setor como meio para ampliar a inclu- } \\
\text { são social, a qualidade de vida dos trabalhadores e a qualidade da prestação de } \\
\text { serviços turísticos no Brasil” (MTur, 2018d: s. p., grifo nosso). }\end{array}$ \\
\hline $\begin{array}{l}\text { 2:Processos de cooperação/coletividade } \\
\text { como estratégias para melhores turismo e } \\
\text { qualificação. }\end{array}$ & $\begin{array}{l}\text { "Fomentar e divulgar a pesquisa científica, ampliando o conhecimento na área do } \\
\text { turismo" (MTur, 2018h: 22, grifo nosso). }\end{array}$ \\
\hline $\begin{array}{l}\text { 3: Qualificação como meio de valorização do } \\
\text { ser humano. }\end{array}$ & $\begin{array}{l}\text { "papel da qualificação profissional e sua relação com a melhora do serviço pres- } \\
\text { tado e a valorização salarial” (MTur, 2018h: 25, grifo nosso) }\end{array}$ \\
\hline
\end{tabular}

Fonte: elaborado pelo autor.

O primeiro é a centralidade nos processos. Nos exemplos das propriedades 1 e 3 , o processo da qualificação figura como um agente de mudança. No da propriedade 2, a coletividade (expressa no processo da pesquisa científica) 
aparece como meio de alcançar objetivos. E ainda, na propriedade 3, o processo de valorização do ser humano consta como um resultado esperado (também de outro processo).

O segundo é a qualificação como vetor para a distribuição de benefícios. No exemplo da propriedade 1, enumeramse benefícios que contemplam grupos excluídos, trabalhadores e mesmo o turista (por meio do serviço). No da propriedade 2, pressupõe-se benefício ao ser humano pela produção de conhecimento. E o último exemplo carrega a ideia de redistribuir parte dos benefícios econômicos ao trabalhador, em detrimento do trade.

Passando para o campo do trabalho, a FD de trabalho alienado apresenta um funcionamento baseado em três processos, exemplificados nas propriedades do Quadro 3.

Quadro 3 - Propriedades discursivas da FD de trabalho alienado Propriedades do discurso 1: A importância da qualificação passa pela capacidade de produção do trabalhador atendido. 2: Conotação positiva aos processos baseados na concorrência.

Exemplos com as marcas formais

Com isso, ampliam-se as relações propositivas que asseguram os direitos dos trabalhadores, assim como a adequação salarial, proporcionando ambientes mais produtivos, com maior segurança e capacitação (MTur, 2018h: 38, grifo nosso)

"Contudo, para o sucesso destes, a formação profissional torna-se prioridade, uma vez que jovens e adultos com formação técnica e com capacidade de se identificarem como sujeitos sociais responsáveis pelo sucesso de seu destino promoveram o aumento da competitividade não apenas entre os empreendimentos locais, mas também entre os municípios com vocação semelhante" (MTur, 2018h: 15, grifo nosso)

3: Oposição entre atividade do trabalho (valorizada) e humanidade (desvalorizada).

Curso de Atendimento ao Turista, apresenta carga horária de 80 horas, composto de 4 (quatro) módulos: [...] Transversal (conteúdo didático que transcende a área de atendimento, mas que é de suma importância para preparação de um cidadão ético e apto a viver em sociedade). (MTur, 2018b: s.p., grifo nosso)

Fonte: elaborado pelo autor.

Na propriedade 1, encontra-se exemplificado o processo de encadeamento. Sua lógica é que a ação da política beneficia determinados atores diretamente, porém sua finalidade recai sobre os benefícios ao capital, representado pelo trade. No exemplo, os direitos do trabalhador servem para aumentar produtividade. Já a propriedade 2 aponta o processo de conotação, pelo qual o texto é dotado de sentidos alinhados ao trabalho alienado. O exemplo demonstra a valorização da competição tanto entre empreendimentos, quanto entre municípios. E a propriedade 3 representa o processo de oposição, que funciona com um método de raciocínio dialético que tem como síntese a valorização do econômico sobre o humano. No exemplo, o curso isola conteúdos de cidadania em apenas um módulo - isto é, a maior parte dos módulos enfoca apenas conteúdos técnicos em detrimento dos conteúdos humanistas.

Na perspectiva oposta, encontra-se a FD de trabalho não alienado. Conforme o Quadro 4, o funcionamento discursivo desta FD se expressa pela centralidade nos processos e pela oposição.

Quadro 4 - Propriedades discursivas da FD de trabalho não alienado
\begin{tabular}{|l|l|}
\hline \multicolumn{1}{|c|}{ Propriedades do discurso } & \multicolumn{1}{c|}{ Exemplos com as marcas formais } \\
\hline $\begin{array}{l}\text { 1: Os processos dão as condições (ca- } \\
\text { racterísticas) de o trabalhador ser su- } \\
\text { jeito do próprio trabalho. }\end{array}$ & $\begin{array}{l}\text { "formação profissional como um direito do cidadão/cidadã, instrumento indispensável } \\
\text { à sua inclusão e aumento de sua permanência no mundo do trabalho, visto que ga- } \\
\text { rante sua autonomia, integração e participação cidadã efetiva na sociedade" (MTur, } \\
\text { 2018h: 32, grifo nosso). }\end{array}$ \\
\hline $\begin{array}{l}\text { 2: Processos baseados na coletividade } \\
\text { como alternativas para as novas deman- } \\
\text { das do mundo do trabalho. }\end{array}$ & $\begin{array}{l}\text { A educação e a qualificação profissional em turismo tornam possível o desenvolvi- } \\
\text { mento territorial a ser garantido na transposição, em um ciclo virtuoso da elevação da } \\
\text { escolaridade, da diminuição da informalidade das ofertas de emprego e da ampliação } \\
\text { do associativismo (MTur, 2018h: 32, grifo nosso). }\end{array}$ \\
\hline $\begin{array}{l}\text { 3: Inverter a desvalorização do ser hu- } \\
\text { mano. }\end{array}$ & $\begin{array}{l}\text { éarantir os direitos dos trabalhadores para proporcionar proteção e segurança, o que } \\
\text { crumano e reduzir o emprego informal" (MTur, 2018h: 34, grifo nosso) }\end{array}$ \\
\hline
\end{tabular}

Fonte: elaborado pelo autor.

A oposição aparece quando a estrutura de significação se dá no antagonismo de termos, conforme exemplifica a propriedade 3. Nela, a valorização do ser humano é oposta à valorização das coisas/desvalorização do ser humano. O trecho destacado aponta uma ação para melhora no trabalho cuja finalidade é incentivar aspectos positivos do labor e negar os aspectos negativos.

Já a centralidade dos processos se dá onde eles aparecem como possibilitadores de melhorias na atividade do trabalho. Na propriedade 1, um processo (formação) é colocado como indispensável para garantir autonomia aos 
cidadãos. Na propriedade 2, um processo social (educação, qualificação) demanda uma mudança que acontece por ações que incluem, além de outros processos (aumento da escolaridade e redução da informalidade), processos baseados na coletividade (associativismo). Assim, os processos aparecem como ações da política, meios para alcançá-la e resultados esperados.

Enfim, no campo da educação, apresenta-se a FD de educação bancária. Das propriedades listadas no Quadro 5, apreende-se que dois processos compõem o funcionamento discursivo desta FD: oposição e falseamento.

Quadro 5 - Propriedades discursivas da FD de educação bancária
\begin{tabular}{|l|l|}
\hline \multicolumn{1}{|c|}{ Propriedades do discurso } & \multicolumn{1}{c|}{ Exemplos com as marcas formais } \\
\hline $\begin{array}{l}\text { 1: A política nega o diálogo e pré-deter- } \\
\text { mina os papéis de educadores, educan- } \\
\text { dos e o seu próprio. }\end{array}$ & $\begin{array}{l}\text { "garantia de educadores comprometidos e portadores de conhecimentos de turismo } \\
\text { nos processos ensino-aprendizagem" (MTur, 2018h, p. 39, grifo nosso) } \\
\text { “O levantamento prévio sobre a aptidão dos interessados pelos cursos, pois essa ação } \\
\text { facilita a maior qualidade dos cursos a serem ofertados, além de contribuir para a apli- } \\
\text { cação dos recursos de forma efetiva" (MTur, 2018h: 44) }\end{array}$ \\
\hline $\begin{array}{l}\text { 2: O conteúdo pedagógico serve ao } \\
\text { mundo do trabalho e ajusta o estudante } \\
\text { a ele. }\end{array}$ & $\begin{array}{l}\text { "Os Projetos Pedagógicos de Cursos Unificados (PPCU) dos cursos técnicos deverão } \\
\text { ser elaborados na forma concomitante com o ensino médio, a partir das ofertas diag- } \\
\text { nosticada no Mapa de Demanda Identificada (MDI)" (MEC, 2017: 6, grifo nosso) }\end{array}$ \\
\hline $\begin{array}{l}\text { 3: Defesa da manutenção do sistema vi- } \\
\text { gente através do silenciamento da polê- } \\
\text { mica. }\end{array}$ & $\begin{array}{l}\text { "Este canal utiliza uma Plataforma de Engajamento e Aprendizagem inovadora e pode } \\
\text { ser acessado por qualquer aparelho tecnológico com internet, como computador, } \\
\text { smartphone, tablet, iPad e outros" (MTur, 2018e: s. p., grifo nosso) }\end{array}$ \\
\hline
\end{tabular}

Fonte: elaborado pelo autor.

A oposição ocorre quando posições são contrastadas, polarizando objetos. Nos exemplos da propriedade 1, são postos papéis que educador e educando devem desempenhar, concebidos como contrários. O educador é "portador" do conhecimento - aquele que possui todo saber. Já o educando é incapaz de aprender algo do qual não tem aptidões prévias - aquele que não possui nenhum saber. Na propriedade 3, a oposição compõe o sentido, contrastando mudança à manutenção do sistema.

Já o falseamento, acontece de formas diferentes. Na propriedade 1, a impessoalidade textual falseia um consenso para pré-determinar posições de educador e educando. Na propriedade 2, falseia-se um benefício intermediário (integração entre projeto pedagógico e ensino médio) para não assumir o benefício direto ao capital (ajuste às demandas identificadas do mercado). E na propriedade 3 a ideia de acesso por qualquer aparelho falseia a possibilidade de qualquer pessoa realizar o curso, ocultando a contratese de que nem todos tem acesso à internet e tecnologia igualmente.

Por último, verifica-se a FD de educação libertadora e problematizadora. As propriedades do Quadro 6 apontam três processos do funcionamento discursivo desta FD: oposição, síntese e encadeamento.

\begin{tabular}{|c|c|}
\hline Propriedades do discurso & Exemplos com as marcas formais \\
\hline $\begin{array}{l}\text { 1: Articulação dos conteúdos e co- } \\
\text { nhecimentos como dever da polí- } \\
\text { tica, em oposição à desarticulação. }\end{array}$ & $\begin{array}{l}\text { “[...] sendo fundamental à educação atual aprender a religar (e não apenas } \\
\text { separar em análises disciplinares)" (MTur, 2018h: 36, grifo nosso). }\end{array}$ \\
\hline $\begin{array}{l}\text { 2: Problematização como alterna- } \\
\text { tiva para questões em detrimento } \\
\text { de uma educação formal irrefletida. }\end{array}$ & $\begin{array}{l}\text { "Considerar, na organização curricular, conhecimentos e didáticas que per- } \\
\text { mitam uma formação para além das competências e habilidades das ocupa- } \\
\text { ções em turismo (ACTs), utilizando-se de pedagogia problematizadora e ecos- } \\
\text { sistêmica" (MTur, 2018h: 41, grifo nosso). }\end{array}$ \\
\hline $\begin{array}{l}\text { 3: A política orienta a articulação } \\
\text { entre educação e mundo. }\end{array}$ & $\begin{array}{l}\text { "Recomenda-se que para a mediação pedagógica no processo de ensino e } \\
\text { aprendizagem, sejam observadas e diagnosticadas as especificidades em re-- } \\
\text { lação ao perfil dos estudantes prevendo ações educativas mais efetivas [...]" } \\
\text { (MEC, 2017: 6, grifo nosso) }\end{array}$ \\
\hline
\end{tabular}

Fonte: elaborado pelo autor.

A oposição aparece nas duas primeiras propriedades, nas quais o discurso funciona a partir da escolha de posições: articulação em detrimento de desarticulação; problematização em detrimento de educação formal. A síntese ocorre na propriedade 3, na qual também há oposição de ideias, porém a oposição gera um resultado terceiro: a educação formal articulada ao mundo fora dela gera uma educação problematizadora. Já o encadeamento (de marcas formais padronizadas) assume papel de indicar a finalidade da qualificação: articulação de conteúdos (propriedade 1); articulação com o mundo (propriedade 3). 
Caracterizadas as partes, os discursos, é possível então identificar nelas o todo, a ideologia que os rege. Assim, a seguir serão apresentadas e analisadas as FI da política de qualificação em turismo.

\section{SER HUMANO, EMPRESARIADO E FORMAÇÕES IDEOLÓGICAS}

Conforme apresentado na seção 1, os atores sociais envolvidos na qualificação profissional são os estudantes/trabalhadores, os empresários, as instituições de ensino e os gestores do Estado. De acordo com Fratucci (2009), os atores envolvidos no turismo são bastante similares: turistas, trabalhadores, empresários, gestores do Estado e população local. A partir disso, são necessárias algumas considerações sobre os atores beneficiados e representados nas formações ideológicas (FI) presentes na política analisada.

Primeiro, no texto desta política, o ator social turista não aparece como um sujeito e, portanto, não tem seus interesses representados de forma autônoma. Segundo, também as instituições educativas, apesar de não aparecerem tão objetificadas quanto o turista, têm pouca agência. Terceiro, ainda que o Estado represente um ator social distinto (tanto no turismo quanto na qualificação profissional), conforme as proposições de Marx (2017) e Mascaro (2013), a classe política dos gestores do Estado não possuem um interesse de classe alternativo aos das classes trabalhadora e capitalista.

Isto significa que os atores efetivamente representados em formações ideológicas que atravessam a política são estudante/trabalhador, educador, população local e trade. Assim, considerando os atores sociais representados nas formações discursivas (FD) pelo texto da política e as posições dos atores nos modelos das teorias utilizadas, foram identificadas duas FI: uma que beneficia o empresariado, o trade; e outra que beneficia o ser humano e a coletividade.

As FD que têm em comum o beneficiamento do empresariado, seja no setor do turismo ou na sociedade em geral, em detrimento dos demais grupos sociais são: turismo duro, trabalho alienado e educação bancária. A partir delas, pode-se caracterizar a FI relativa ao empresariado.

Primeiro, ela utiliza mecanismos de significação que ocultam do texto material os significados que defende. Estes significados tratam dos interesses do empresariado, da utilização de outros atores como objeto, da competição, da desvalorização do ser humano e da manutenção do sistema capitalista. 0 uso de mecanismos para ocultação dos significados defendidos pode ser atribuído à parcialidade destes significados (que teoricamente deve ser evitada em uma política pública) e à desvalorização ou prejuízos que implicam nos demais atores sociais em ordem de manter o sistema capitalista de exclusão e concorrência.

Em seguida, o funcionamento da FI demonstra essa característica também com os processos que usa: a conotação positiva de processos do sistema capitalista aponta para a parcialidade; em função disso, a oposição aparece para ocultar posições contrárias e oprimir divergências, criando a aparência de não haver polêmica e outras possibilidades de posições; e, ao simular que não existe um posicionamento parcial, é utilizado o falseamento para que, ao nível da aparência, o estudante/trabalhador seja o beneficiado, enquanto o real beneficiado é o empresariado.

Portanto, esta FI representa os interesses do empresariado por meio dos mecanismos de ocultação de polêmicas e de falseamento de benefícios.

Já as FD de turismo suave, de trabalho não alienado e de educação libertadora têm em comum o beneficiamento do ser humano - de certa forma como indivíduo (universal), mas também como coletividade. O ser humano aparece na figura da população residente, do trabalhador, do educando e do educador, eventualmente até do próprio empresário (como integrantes da coletividade).

A combinação de mecanismos de significação desta FI revela uma preferência pela explicitação dos significados e posicionamentos ideológicos no texto da política. Tais significados são relacionados a: cooperação e coletividade; protagonismo dos atores desfavorecidos; valorização do ser humano; autonomia; e reflexão da própria atividade pelo indivíduo. A função, em teoria, de uma política pública ajuda igualmente a entender esta relação. A política pública é ou deveria ser, por um lado, voltada ao todo da sociedade, e por outro, dedicada à redução de desigualdades. Neste sentido, os significados de coletividade e valorização dos grupos desfavorecidos podem ser postos no texto sem sanções - e, ainda mais, devem ser colocados como justificativa da política pública.

Já o funcionamento desta FI converge três aspectos para o mesmo resultado. A centralidade nos processos colocaos como meio de gerar os benefícios para o ser humano. A finalidade da qualificação para melhoria de vida da 
coletividade aponta a distribuição equitativa de benefícios entre os atores - contemplando todos os atores e, ao mesmo tempo, compensando as disparidades de poder dos desfavorecidos. E a oposição apresenta perspectivas antagônicas para que se possa argumentar em favor daquela relacionada à valorização do ser humano.

Assim, fica claro que esta Fl representa os interesses do ser humano e da coletividade por meio da defesa de posicionamentos - a partir da explicitação de perspectivas opostas - e da defesa de que a qualificação tem como função a distribuição equitativa de benefícios entre os atores sociais evolvidos.

Identificadas a existência e o perfil das FI, passa-se então à análise das relações de disputa entre elas sobre a política de qualificação em turismo.

\subsection{Disputa política nos âmbitos do discurso e da aparência}

As duas FI são diretamente opostas, na medida em que representam a defesa de diferentes arranjos de poder na relação entre empresariado e ser humano. A FI representante do empresariado utiliza mecanismos que ocultam os significados do texto formal e os localiza no não dito e em outros discursos; enquanto a Fl representante do ser humano evita tais mecanismos e privilegia aqueles que formalizam suas posições no texto, explicitando os significados que defende.

Por outro lado, a FI do empresariado só pode esconder seus significados porque há outro significado, diferente do seu, explícito. Isto é, a primeira usa a segunda para se mascarar. Daí se apreende que a relação entre as duas FI é dialógica - antagonizam-se e complementam-se.

Embora a FI do ser humano se complemente da outra, utilizando o espaço deixado pelo silêncio e pelo implícito, a FI do empresariado ainda é dominante. Isso porque ela é falseada: a FI do empresariado não se coloca, não se posiciona e isto the permite se apropriar da outra, tomar os significados dela como seus na aparência e minar o senso de equidade com os interesses do empresariado. Assim como o capital explora o trabalhador, a FI do empresariado explora a postura da FI do ser humano com seu falseamento.

Quanto ao funcionamento das FI, há uma aproximação no sentido dos seus processos de significação tratarem de aspectos em comum: os processos envolvidos na qualificação profissional, os interesses dos atores envolvidos e a oposição de posicionamentos. Percebe-se aqui um caráter hologramático: tais aspectos do fenômeno da qualificação, como um todo, se manifestam nos diferentes discursos que lhe atravessam suas partes. A aproximação revela, por outro lado, o distanciamento entre as $\mathrm{Fl}$, uma vez que, frente aos mesmos aspectos, elas tomam direções diferentes. A FI representante do empresariado valoriza os processos que mantém o sistema capitalista e os interesses do capital usando a oposição como ocultação de posicionamentos divergentes. Já a $\mathrm{FI}$ representante do ser humano valoriza os processos de distribuição de benefícios e, consequentemente, os interesses da coletividade, usando a oposição para embasar explicitamente seus posicionamentos. Assim, percebese também uma dialógica, na qual os discursos, que se complementam como expressões do mesmo todo da qualificação, se opõem como expressões antagônicas.

Neste âmbito também a FI que representa o empresariado estabelece dominância - e isto se deve à interdiscursividade no funcionamento delas. A FI do ser humano funciona explicitando seus significados, esclarecendo suas posições e apontando o beneficiamento da coletividade. Ela não se dedica a combater a argumentação e o funcionamento da Fl oposta. Já a FI do empresariado, não pode se assumir como uma ideologia que defende a exploração, a exclusão e a opressão, então ela incorpora o funcionamento da outra FI de tal forma que a outra apareça como parte de si, um trecho da sequência que encadeia qualificação aos interesses do empresariado. Essa dinâmica pode ser representada conforme a Figura 2.

Assim, apreende-se uma dominância da FI que representa os interesses do empresariado no funcionamento discursivo. Entretanto, uma lógica diferente é apresentada por um segundo aspecto: a quantidade das passagens de cada FI.

Quando agrupadas as FD, o número de passagens da FI representante do ser humano é quase o dobro da FI oposta. Inicialmente parece incoerente que a $\mathrm{FI}$ do empresariado estabeleça uma dominância discursiva quando, materialmente, o texto apresente muito mais a defesa da FI do ser humano. Mesmo que a FI do empresariado se utilize da outra para falsear seu funcionamento, o alto número de passagens da FI do ser humano não deixa de ser um aspecto relevante para exercer uma dominância - isto é, a FI do ser humano é dominante na aparência. De 
certa forma, isso fortalece também seus significados, pois são eles que a sociedade vê defendida - enquanto os interesses do empresariado são escondidos e mascarados, de tal forma que sua revelação pode gerar estranhamento e negação pela sociedade.

Figura 2 - Funcionamento das Formações Ideológicas

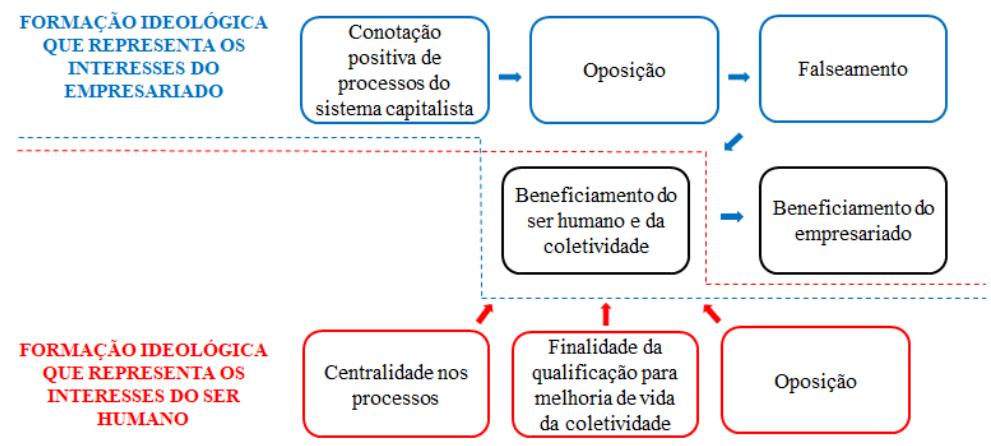

Fonte: elaborado pelo autor.

É possível observar, assim, uma dialógica entre as $\mathrm{Fl}$, na qual a representante do empresariado domina o funcionamento discursivo e a representante do ser humano domina a aparência. Entretanto, dois aspectos aprofundam a complexidade desta relação.

Primeiro, em relação à quantidade de passagens do texto, a FD de trabalho alienado é superior à de trabalho não alienado, enquanto a de educação libertadora é superior à de educação bancária.

Educação libertadora e trabalho alienado são, por princípios, direcionamentos antagônicos. Porém, se complementam na política, que aponta um processo em que uma educação baseada na libertação será absorvida por um mercado de trabalho baseado na alienação. Existe, então, uma relação dialógica entre essas FD. Como consequência dessa complementariedade, a educação libertadora deixa de ser exclusiva da aparência para entrar no âmbito da prática, ao passo que o trabalho alienado deixa a ocultação para compor também a aparência. Isso complexifica a predominância das FI sobre os aspectos de discurso e aparência, ampliando a dialógica em ambos e dando-Ihes também um caráter recursivo. O conflito ideológico componente dos discursos produz e é (re)produzido pela aparência.

Segundo, ao discriminar a frequência das FI nas iniciativas do Brasil + Turismo e na PNQT, fica evidente uma polarização. As iniciativas do Brasil + Turismo têm maior presença da FI do empresariado e a PNQT tem maior presença da $\mathrm{FI}$ do ser humano.

A PNQT representa o planejamento estratégico da política, as diretrizes político-metodológicas para o funcionamento de toda ação do poder público na qualificação em turismo. Por outro lado, as iniciativas do Brasil + Turismo corresponderam, durante todo o tempo em que não houve PNT e PNQT, diretamente à ação do poder público. O fato de o PNT 2018-2022 legitimar as duas vertentes sem um esforço detalhado de articulação entre elas gera um conflito: por um lado a PNQT é um planejamento estratégico sem ação prática e, por outro, o Brasil + Turismo é uma ação prática sem planejamento estratégico. Assim, tanto a dicotomia planejamento/prática quanto a predominância das FI colocam as duas vertentes da política como antagônicas.

Essa dicotomia, porém, se complexifica. Enquanto a FI que representa os interesses da coletividade se estabelece no planejamento estratégico, na PNQT, a FI do empresariado predomina na prática e falseia a ideia de que a prática está refletindo a defesa dos interesses da coletividade previstos no planejamento. Dessa forma, mesmo o planejamento sendo ideologicamente oposto à prática, ele a complementa como uma validação ou justificativa (ainda que falseada). Mais uma vez, a Fl que representa o empresariado se apropria da dialógica para estabelecer uma dominância.

Desta forma, é possível compreender que as duas FI - representante do empresariado e representante do ser humano - estão presentes na dimensão política da política pública nacional de qualificação profissional em turismo. Frente aos antagonismos e complementariedades entre as duas, a FI do empresariado estabelece uma dominância porque consegue incorporar esta dialógica e fazer a FI do ser humano servir ao seu propósito. 


\section{CONSIDERAÇÕES FINAIS}

A análise das formações discursivas (FD) revelou as concepções ideológicas - de turismo, trabalho e educação em confronto na política pública nacional de qualificação profissional em turismo vigente de 2017 a 2018 . $\mathrm{Na}$ remissão delas às formações ideológicas (FI), pôde-se analisar a disputa política entre os atores sociais interessados nos benefícios e prejuízos da qualificação profissional.

Os benefícios apontados pelo texto da política não são, necessariamente, falsos: a política pública, com seus objetivos programáticos, precisa apontar para determinados benefícios à sociedade e orientar a atuação do Estado para esta direção. Porém, a contribuição da AD foi ultrapassar a aparência da política e tornar evidente aqueles benefícios e atores beneficiados decorrentes do funcionamento ideológico que direciona a própria atuação do Estado. Isto é, se no texto (na aparência) são listados benefícios que atendem os interesses de determinados atores sociais, não necessariamente os mesmos interesses são contemplados pelo posicionamento (ideologia) que o Estado segue no cumprimento desta política pública. Desta maneira, observou-se que a política analisada atende o interesse de um ator (ser humano/coletividade) por seus benefícios diretos/aparentes, mas usa este atendimento de interesses como meio para uma finalidade que atende interesses de outro ator (empresariado). Tal modo de atuação discursiva do Estado corrobora o que Tasso, Moesch e Nóbrega (2021) apontaram como "dissociação entre 'políticas públicas' e 'ética'” - ou seja, a política pública sobrepondo interesses do campo econômico à sua função (publicamente assumida) de atender aos interesses da população como um todo.

Com a análise dos aspectos discursivos e de aparência textual, ficou claro que a disputa política está presente e atuante no texto da política analisada. Por mais que a FI do empresariado estabeleça dominância, não é de forma segura e estável. Há espaços onde a FI do ser humano predomina: a aparência, o espaço discursivo sobre educação, o planejamento estratégico da PNQT. E há relações dialógicas e recursivas de complementariedade intrínseca, onde a FI do empresariado só pode existir, funcionar e dominar por causa da existência e funcionamento da própria FI do ser humano. Isto é, a FI do empresariado não pode suprimir totalmente a FI do ser humano, mas a presença da segunda é sempre uma ameaça à primeira, pois está sempre em disputa.

Assim, as duas ideologias tendem a permanecer convivendo. Não pode haver vitória de uma sobre a outra, apenas dominância e direção. 0 embate entre as duas se faz pela incorporação dialógica: FI sobre Fl; discurso sobre aparência; ação prática sobre planejamento estratégico. Na política pública nacional de qualificação profissional em turismo estabelecida entre 2017 e 2018, essa dominância estava atrelada à FI que representa os interesses do empresariado. Portanto, a mudança ou manutenção dessa dominância só pode se fazer na disputa pela dialógica das relações entre as ideologias.

Cabe destacar que esse tipo de relação dialógica entre discursos que atendem ao empresário e ao trabalhador também vem sendo observadas na prática das relações econômicas. Silva, Silva e Santos (2021) demonstram como essa ambivalência discursiva está presente no pensamento de trabalhadores do setor de agencias de turismo. Esse cenário aponta para a necessidade de futuras investigações sobre como (ou se) essa dialógica entre ideologias presente nas políticas de qualificação vem sendo transmitida para a consciência coletiva dos trabalhadores do turismo.

Espera-se que os resultados da presente pesquisa possam contribuir, primeiramente, para a atuação da classe trabalhadora. Como apresentado, o Estado é uma instituição na qual as classes sociais disputam politicamente pela representação de seus interesses. As políticas públicas materializam essa disputa e são um espaço importante para atuação das classes e atores sociais.

No âmbito do turismo, as políticas do MTur representam esse espaço e sua política de qualificação profissional, em especial, está diretamente ligada às relações fundamentais entre trabalhadores e capitalistas do setor do turismo. Ao desvelar as formas de predominância ideológica dessa política, a presente pesquisa possibilita um conhecimento mais apurado da situação das classes e relação à qualificação para o turismo. Dado que a política de qualificação do MTur beneficia a classe capitalista em detrimento da classe trabalhadora, essa pesquisa é uma ferramenta para que os trabalhadores do turismo possam repensar sua importância dentro das políticas do MTur e potencialmente exigir que suas necessidades sejam atendidas para além do nível da aparência.

Em termos metodológicos, a presente pesquisa também contribui com o desenho de um modelo para o método de Análise de Discurso que contempla e integra, por meio do paradigma da complexidade, os saberes de áreas 
múltiplas (turismo, trabalho, educação e política) e as posições de atores sociais diversos (turistas, trabalhadores, empresários, gestores do Estado, população local). Nesse sentido, espera-se que as contribuições aqui presentes sejam úteis não apenas para o entendimento da política de qualificação analisada, mas para outras políticas públicas. A partir do ferramental metodológico da Análise de Discurso, ambos, pesquisadores e trabalhadores do turismo, podem buscar as determinações ideológicas que regem a atuação estatal em relação ao setor do turismo.

Essa pesquisa inicia um esforço de análise dos discursos e ideologias presentes e predominantes nas políticas públicas do turismo que está longe de esgotar suas possibilidades. Futuras pesquisas podem acrescer esse esforço inicial em três direções: 1) ampliar o recorte temporal da análise da política de qualificação; 2) investigar as ações de qualificação advindas dessa política na prática, identificando os desdobramentos das formações ideológicas que predominam no âmbito das diretrizes e contrastando as duas realidades; 3) expandir essa análise para as demais políticas do MTur, integrando os resultados a fim de observar o posicionamento do órgão na disputa das classes sociais. A qualificação profissional tem sido objeto de dimensões cada vez maiores entre as políticas do MTur e, portanto, pode representar um caminho oportuno para os estudos do campo do turismo (re)interpretarem o poder público federal frente às mudanças constantes em seus arranjos institucionais.

\section{AGRADECIMENTOS}

Agradecemos o apoio financeiro da Fundação de Amparo à Pesquisa do Estado do Rio de Janeiro (FAPERJ), concedido para realização de parte da pesquisa. E agradecemos, especialmente, à Professora Doutora Erly Maria de Carvalho e Silva por ter nos apresentado ao método da Análise de Discurso.

\section{REFERÊNCIAS}

Brasil. (2008). Lei $n^{\circ}$ 11.771, de 17 de setembro de 2008. Dispõe sobre a Política Nacional de Turismo. Brasília. Recuperado em set. 09, 2020 de: http://www.planalto.gov.br/ccivil 03/Ato20072010/2008/Lei/L11771.htm.

Brasil. (2011). Lei n ${ }^{\circ}$ 12.513, de 26 de outubro de 2011. Institui o Programa Nacional de Acesso ao Ensino Técnico e Emprego (Pronatec)... Brasília. Recuperado set. 09, 2020 de: http://www.planalto.gov.br/ccivil_03/_Ato2011-2014/2011/Lei/L12513.htm.

Brandão, H. (2012). Introdução à análise do discurso. Editora da Unicamp.

Catramby, T.; Costa, S. (2004). Qualificação Profissional em Turismo como Fator de Competitividade do Setor. Caderno Virtual de Turismo, 4 (3), p. 26-34.

Cisne, R. (2016) Processos entre Ensino, Aprendizagem e Avaliação: Uma Experiência em Curso no Turismo. Revista Rosa dos Ventos - Turismo e Hospitalidade, 8 (IV), p. 555-574, out./dez. http://dx.doi.org/10.18226/21789061.v8i4p555

Conceição, R.; Fraga, T.; Conceição, M. (2016). Qualificação Profissional: um panorama comparativo entre hotéis e pousadas do primeiro distrito de Petrópolis - RJ. Turismo em Análise, 27 (1), abr. http://dx.doi.org/10.11606/issn.1984-4867.v27i1p178-206.

Eagleton, T. (2009). Ideologia: uma introdução. São Paulo, Boitempo.

Feger, J.; Freitas, M.; Kuntz, V.; Sehn, M.; Santos, L. (2015). Cursos Pronatec Copa 2014 Voltados ao Turismo em Curitiba, PR: Instrumento de Avaliação por Rubrica. Revista Rosa dos Ventos - Turismo e Hospitalidade, 7 (3), p. 319-337, jul./set. http://dx.doi.org/10.18226/21789061.v7iss3p319.

Ferretti, C. (2004). Considerações sobre a apropriação das noções de qualificação profissional pelos estudos a respeito das relações entre trabalho e educação. Educação \& Sociedade, 25 (87), p. 401-422. https://doi.org/10.1590/S0101-73302004000200006

Fratucci, A. (2009). Refletindo Sobre a Gestão dos Espaços Turísticos: perspectivas para as redes regionais de turismo. Turismo em Análise, 20 (3), dez. https://doi.org/10.11606/issn.1984-4867.v20i3p391-408

Fratucci, A.; Bantin, N.; Melo, R. (2017). O Pronatec Turismo para além da empregabilidade: Percepções na cidade do Rio de Janeiro - RJ (Brasil). Revista Turismo \& Desenvolvimento, 27/28.

Freire, P. (2016). Pedagogia do oprimido. Rio de Janeiro, Paz e Terra.

Frey, K. (2000). Políticas públicas - um debate conceitual e reflexões referentes à prática da análise de políticas públicas no Brasil. Planejamento e Políticas Públicas, 21, p. 211-259. 
Krippendorf, J. (2009). Sociologia do turismo: para uma nova compreensão do lazer e das viagens. São Paulo, Aleph.

Martoni, R.; Alves, K. (2019) As condições da classe trabalhadora em atividades características do turismo: especificidades e tendências socioprodutivas. Rosa dos Ventos - Turismo e Hospitalidade, 11 (1), p. 211-223, jan./mar. http://dx.doi.org/10.18226/21789061.v11i1p211.

Marx, K. (2008). Manuscritos econômico-filosóficos. São Paulo, Boitempo.

Marx, K. (2010). O capital: edição condensada. São Paulo, Folha de São Paulo.

Marx, K. (2017). O capital: crítica da economia política: livro I: o processo de produção da mercadoria. São Paulo, Boitempo.

Mascaro, A. (2013). Estado e forma política. São Paulo, Boitempo.

Maranhão, C.; Brandão, P.; Pequeno, E.; Aires, J. (2010). Direcionamentos para as políticas públicas de turismo no Rio Grande do Norte, com foco na orientação do turismo pró-pobre. INTERFACE, Natal/RN, 7 (2), jul./dez.

Meira, C.; Kushano, E.; Neves, C. (2018). Qualificação profissional técnica no contexto das políticas públicas de turismo e as novas perspectivas do plano nacional de turismo 2018 - 2022. Revista Ateliê do Turismo, Campo Grande, 1 (2), p. 46-66, jul./dez.

Ministério da Educação. (2017). Guia - Médiotec. Brasília. Recuperado em set. 03, 2020 de: http://portal.mec.gov.br/docman/maio-2017-pdf/64871-guia-meiotec-2017-pdf/file.

Ministério da Educação. (2018). MedioTec. Brasília. Recuperado em set. 03, 2020 de: http://portal.mec.gov.br/mediotec/apresentacao-mediotec.

Ministério do Turismo. (2013a). Perguntas frequentes. Recuperado em set. 03, 2020 de: http://www.pqi.turismo.gov.br/site/conheca-o-programa.html.

Ministério do Turismo. (2013b). Conheça o programa. Recuperado em set. 03, 2020 de: http://www.pqi.turismo.gov.br/site/conheca-o-programa.html.

Ministério do Turismo. (2017a). Portaria $n^{\circ}$ 46, de 4 de abril de 2017. Brasília. Recuperado em set. 03,2020 de: http://www.turismo.gov.br/portaria-n\%C2\%BA-46-de-4-de-abril-de-2017.html.

Ministério do Turismo. (2017b). Portaria $n^{\circ}$ 8, de 6 de janeiro de 2017. Brasília. Recuperado em set. 03, 2020 de: http://www.turismo.gov.br/portaria-n\%C2\%BA-8-de-6-de-janeiro-de-2017.html.

Ministério do Turismo. (2018a). MédioTec presencial. Recuperado em set. 03, 2020 de: http://www.turismo.gov.br/assuntos/7957-mediotec.html.

Ministério do Turismo. (2018b). Brasil braços abertos: Perguntas frequentes. Recuperado em set. 03,2020 de: http://www.turismo.gov.br/assuntos/7857-perguntas-mais-frequentes-\%E2\%80\%93-brasilbra\%C3\%A7os-abertos.html.

Ministério do Turismo. (2018c). Brasil braços abertos: Sobre. Recuperado em set. 03, 2020 de:http://www.turismo.gov.br/assuntos/11530-brasil-bra\%C3\%A7os-abertos-inscri\%C3\%A7\%C3\%B5es-2018.html.

Ministério do Turismo. (2018c). Curso gestor de turismo: Perguntas frequentes. Recuperado em set. 03,2020 de: http://www.turismo.gov.br/assuntos/11771-perguntas-mais-frequentes-gestor-de-turismo.html.

Ministério do Turismo. (2018e). Curso gestor de turismo: Sobre. Recuperado em set. 03, 2020 de: http://www.turismo.gov.br/assuntos/11538-curso-gestor-de-turismo.html.

Ministério do Turismo. (2018f). Pronatec. Recuperado em set. 03, 2020 de: http://www.turismo.gov.br/assuntos/7959-pronatec-turismo.html.

Ministério do Turismo. (2018g). Perguntas mais frequentes - Pronatec voluntário EAD. Recuperado em set. 03, 2020 de: http://www.turismo.gov.br/assuntos/7858-perguntas-mais-frequentes-\%E2\%80\%93-pronatecvolunt\%C3\%A1rio-ead.html.

Ministério do Turismo. (2018h). Política nacional de qualificação no turismo. Brasília. Recuperado em set. 03, 2020 de: http://www.turismo.gov.br/images/pdf/Publica\%C3\%A7\%C3\%B5es/PlanoPNQT A4 64pgs 2019.pdf.

Moreira, M.; Campos, G. (2019). O ritual da interpelação ideológica no Turismo LGBT e a impossibilidade do desejo que se desloca. Revista Brasileira de Pesquisa em Turismo, São Paulo, 13 (2), p. 54-68, maio/ago. http://dx.doi.org/10.7784/rbtur.v13i 2.1542. 
Morin, E. (2006). Introdução ao pensamento complexo. Porto Alegre, Sulina.

Nogueira, E.; Costa-Neto, C.; Silva, G. (2013). Qualificação profissional como suporte para implantação do etnoturismo na comunidade indígena Ingarikó (RR). Revista Brasileira de Ecoturismo, São Paulo, 6 (2), p. 424441, mai./jul. https://doi.org/10.34024/rbecotur.2013.v6.6120

Orlandi, E. (2003). A linguagem e seu funcionamento: as formas do discurso. Campinas, Pontes.

Orlandi, E. (2015). Análise de Discurso: princípios e procedimentos. Campinas, Pontes.

Parente, F; Moesch, M. (2016). Desafios das políticas de qualificação para um turismo mais humanizador. Anais do Seminário da ANPTUR.

Paula, A.; Herédia, V. (2019). Qualificação profissional de camareiras de hotéis e a crítica que Paulo Freire não escreveu. Revista de Turismo Contemporâneo, Natal, 7 (1), p. 141-162, jan./jun. https://doi.org/10.21680/2357-8211.2019v7n1ID16783

Pimentel, T. D.; Paula, S. C.; Oliveira, M. C. (2016). Uma reflexão sobre a qualificação na formação em turismo: relevância da micro e pequena empresa para o destino turístico. Turismo y Sociedad, 18, p. 159-177, jan./jun. https://doi.org/10.18601/01207555.n18.09

Rosa, N. (2016). As implicações teórico-metodológicas e a concepção turismo de massa na obra Sociologia do Turismo de Jost Krippendorf. Dissertação (Mestrado - Mestrado Profissional em Turismo) - Universidade de Brasília.

Silva, I. (2020). Políticas públicas e qualificação profissional em turismo: uma análise das metodologias de pesquisa. Observatório de Inovação do Turismo - Revista Acadêmica, XIV (3), dez. https://doi.org/10.17648/raoit.v14n3.6027

Silva, I.; Silva, M.; Santos, M. (2021). Condições de trabalho em casa durante a pandemia: uma análise do discurso do sujeito coletivo dos trabalhadores do setor de agências de turismo. Revista Brasileira de Pesquisa em Turismo, São Paulo, 15 (1), 2200. http://dx.doi.org/10.7784/rbtur.v15i12200

Soares, J.; Godoi, C. (2017). A metodologia da análise sociológica do discurso em estudos turísticos: o processo de transformação da imagem turística e sua relação com a lealdade. PASOS. Revista de Turismo y Patrimonio Cultural, 15 (1), jan. https://doi.org/10.25145/j.pasos.2017.15.015

Souza, D; Gastal, S.; Campos, L. (2017). Relação entre Sujeito, Turismo e Trabalho. Revista Hospitalidade, São Paulo, 14 (2), p. 01-19, ago. https://doi.org/10.21714/2179-9164.2017v14n2.766

Tasso, J. P. F.; Moesch, M. M.; Nóbrega, W. R. M. (2021) Reincorporação da Ética às Políticas Públicas de Turismo: uma necessária reflexão no combate às consequências do Covid 19. Revista Brasileira de Pesquisa em Turismo, São Paulo, 15 (1), p. 21-41, jan./abr. http://dx.doi.org/10.7784/rbtur.v15i1.2141

Tomazoni, E. (2007). Educação Profissional em Turismo. Cria-se Mercado pela Formação? Turismo em Análise, 18 (2), p. 197-219, nov. https://doi.org/10.11606/issn.1984-4867.v18i2p197-219

Vilela, G.; Costa, H. (2020). Políticas Públicas de Turismo: uma análise dos planos nacionais de turismo do Brasil (2003- 2022). RTA, 31 (1), p. 115-132, jan./abr. http://dx.doi.org/10.11606/issn.1984-4867.v31i1p115132.

\section{Informações dos Autores}

\section{Ivan Conceição Martins da Silva.}

Mestre em Turismo pela Universidade Federal Fluminense (UFF) e Bacharel em Turismo pela Universidade Federal do Estado do Rio de Janeiro (UNIRIO). Membro do Grupo de Pesquisa Turismo, gestão e territórios (UFF) e do Núcleo de Pesquisas em Politicas Publicas de Turismo, da Universidade de Brasília (UnB).

Contribuições: Concepção da pesquisa. Revisão da literatura. Coleta de dados. Análise de dados. Discussão.

E-mail: ivanmartins@id.uff.br

ORCID: https://orcid.org/0000-0003-3353-3463

\section{Aguinaldo Cesar Fratucci}

Professor Associado do Departamento de Turismo da Faculdade de Turismo e Hotelaria (FTH) da Universidade Federal Fluminense (UFF). Doutor (2008) e Mestre (2000) em Geografia pela Universidade Federal Fluminense, especialista na área de planejamento turístico e gestão de políticas públicas de turismo. Líder do Grupo de Pesquisa Turismo, gestão e territórios. Contribuições: Concepção da pesquisa. Revisão da literatura. Discussão.

E-mail: acfratucci@turismo.uff.br

ORCID: https://orcid.org/0000-0003-4267-4399 